Krzysztof Tarka (Opole)

\title{
„Jesteśmy tu dla Polski”. III Rada Narodowa RP wobec wydarzeń w kraju (1949-1951)
}

\section{WSTĘP}

Wobec niemożności przeprowadzenia wolnych i demokratycznych wyborów w Polsce prezydent RP na uchodźstwie August Zaleski 13 września 1948 r. wydał dekret o powołaniu Rady Narodowej Rzeczypospolitej Polskiej. Była to już trzecia Rada Narodowa od wybuchu II wojny światowej. Pełniąc zastępczo niektóre funkcje parlamentu była ona organem doradczym prezydenta i rządu. Zgodnie z dekretem Rada wydawała opinie w sprawach wnoszonych przez rząd na jej sesje. Rząd przynajmniej dwa razy do roku miał przedstawiać Radzie wyniki swojej działalności oraz zamierzenia na przyszłość. Rada podejmowała również uchwały w sprawach budżetowych, dotyczących funduszów pochodzących „,z ofiarności publicznej”. Uchwały Rady zapadały zwykłą większością głosów przy udziale co najmniej jednej trzeciej ogólnej liczby członków. Rada mogła także zwracać się do rządu o wydanie aktów prawnych oraz o wyjaśnienie stanowiska w sprawach wiążących się z jego zadaniami. Kadencja Rady trwała dwa lata. Jej sesje zwoływał, otwierał i zamykał prezydent, który mógł również na wniosek premiera rozwiązać Radę przed upływem kadencji. Rada składała się co najmniej z 15, a najwyżej z 40 członków, których mianował i odwoływał prezydent. Członkowie Rady ze swego grona wybierali przewodniczącego, wiceprzewodniczących i sekretarza. W skład Rady Narodowej nie mogli wchodzić ministrowie, prezes Najwyższej Izby Kontroli oraz inni urzędnicy i funkcjonariusze państwowi, a także żołnierze w służbie czynnej ${ }^{1}$.

\footnotetext{
${ }^{1}$ Dekret o powołaniu Rady Narodowej RP z 13.09.1948 r. zob. R. Turkowski, Parlamentaryzm polski na uchodźstwie 1945-1972 w okresie rozbicia emigracji politycznej w Londynie, Warsza-
} 
W maju 1949 r., gdy fiaskiem zakończyły się próby pojednania zwolenników prezydentury Augusta Zaleskiego i antyprezydenckiej opozycji na emigracji z Polską Partią Socjalistyczną i Stronnictwem Narodowym na czele, prezydent mianował 29, a następnie kolejnych 11 członków Rady Narodowej RP. Utworzenie III Rady Narodowej przyczyniło się do skonsolidowania ugrupowań tworzących obóz prezydencki (,zamek”). Mandaty do Rady otrzymali przedstawiciele piłsudczykowskiej Ligi Niepodległości Polski, Stronnictwa Ludowego „Wolność”, Komitetu Zagranicznego Stronnictwa Pracy, grupka socjalistów, którzy utworzyli później Związek Socjalistów Polskich, przedstawiciele Związków Ziem Wschodnich RP, kombatanci (niebawem utworzyli Niezależną Grupę Społeczną) oraz duchowni katoliccy, prawosławni i protestanccy².

\section{OTWARCIE III RADY NARODOWEJ}

Inauguracyjne posiedzenie III Rady Narodowej odbyło się 6 czerwca 1949 r., a jej przewodniczącym został Tytus Filipowicz. W ciągu dwóch lat istnienia Rady sytuacja w Polsce była jednym z głównych zagadnień poruszanych na jej forum. Otwierając posiedzenie Rady prezydent Zaleski przypomniał, że Polska nadal nie jest wolna i ,jęczy w straszliwej niewoli”. W ocenie głowy państwa na wychodźstwie sytuacja w kraju przypominała zakamuflowaną okupację: „najeźdźca - stwierdził prezydent - znalazł garść Polaków, którzy posłużyli mu za narzędzie do kamuflowania okupacji”. W tej sytuacji naród polski nie mógł ponosić odpowiedzialności za „narzucone sobie przez obcych rządy”. Ponieważ kraj nie mógł wypowiedzieć swobodnie swej woli, to na emigracji ciążył obowiązek walki

wa 2001, s. 291-293. Szerzej na temat I (1939-1941) i II Rady Narodowej RP (1942-1945), zob. E. Duraczyński, R. Turkowski, O Polsce na uchodźstwie. Rada Narodowa Rzeczypospolitej Polskiej 1939-1945, Warszawa 1997.

2 A. Friszke, Życie polityczne emigracji, Warszawa 1999, s. 109-111; G. Kulka, Komisje prawno-ustrojowe Rady Narodowej RP na emigracji w latach 1939-1991, Warszawa 2009, s. 89-91; R. Turkowski, op.cit., s. 54-56. Po śmierci prezydenta Władysława Raczkiewicza w czerwcu 1947 r. emigrantów podzielił spór o obsadę stanowiska głowy państwa. Konkurentami do fotela prezydenckiego byli Tomasz Arciszewski, premier rządu, desygnowany w 1944 r. na następcę prezydenta, oraz August Zaleski, były minister spraw zagranicznych i urzędujący szef kancelarii cywilnej prezydenta, którego śmiertelnie chory Raczkiewicz w ostatnich tygodniach życia wyznaczył swoim następcą. Zmiany tej nie uznał Arciszewski i jego stronnictwo - Polska Partia Socjalistyczna. Zapoczątkowany w 1947 r. spór o prezydenturę ciągnął się przez następne ćwierć wieku. Jeszcze w końcu czerwca 1947 r. opozycyjne partie z PPS na czele utworzyły Koncentrację Demokratyczną. W listopadzie 1948 r. PPS oraz PSL i odłam SP Karola Popiela utworzyły Porozumienie Stronnictw Demokratycznych. Pozycja prezydenta Zaleskiego uległa znacznemu osłabieniu, gdy wiosną 1949 r. „zamek” opuściło Stronnictwo Narodowe. W grudniu 1949 r. PPS wraz z SN i PRW „NiD” powołały Radę Polityczną. O sporach i przetasowaniach w „,polskim” Londynie zob. A. Friszke, op.cit., s. 71-146. 
o Polskę wolną, niepodległą i całą. Wobec zadań stojących przed emigrantami Zaleski apelował o jedność wychodźstwa: „musimy zdać sobie sprawę z tego, że mamy przed sobą jeszcze ciężkie, a może długie walki, nim spełnią się nasze zasadnicze postulaty i że każda wewnętrzna walka o rzeczy nie będące dziś bezpośrednio na porządku dziennym utrudnia nam tylko spełnienie głównego naszego zadania"3. Po wyborze władz III Rady Narodowej jej przewodniczący Tytus Filipowicz deklarował: ,jesteśmy tu dla Polski i tylko dla Polski”4.

Na zakończenie pierwszego dnia obrad Rady premier Tadeusz Tomaszewski przedstawił program i zadania swojego rządu. Końcową część przemówienia poświęcił sytuacji w kraju. Premier zapewniał, że rząd z uwagą obserwuje wydarzenia w Polsce i gromadzi dotyczące jej materiały. Wiadomości nadchodzące z Polski wskazywały, że kraj zmierza do „zupełnej sowietyzacji”. Mimo wzrastającego terroru szef rządu na uchodźstwie apelował do rodaków w kraju, aby stawiając bierny opór wobec nacisku sowieckiego oszczędzali siły i wytrwali w „spokojnej postawie”, która - nie tylko w jego ocenie - była ,jedynie słuszna”. Przestrzegał też przed marnowaniem krwi polskiej „,w bezcelowych aktach rozpaczy”. Podobnie jak prezydent, zaznaczył, że ciężar prowadzenia akcji politycznej w sprawie Polski spoczywa na emigracji, a zwłaszcza na rządzie RP5

Pogląd Tomaszewskiego na sytuację w Polsce i zadania emigracji podzielał Stanisław Sopicki z Klubu Chrześcijańsko-Społecznego. Podczas dyskusji nad exposé premiera 9 czerwca podkreślił, że „wzywanie Kraju do marnowania sił w beznadziejnych próbach walki zbrojnej byłoby wielkim i tragicznym błędem”. Dodał, że podobne stanowisko zajmowały również wcześniejsze rządy Tomasza Arciszewskiego i Tadeusza Bór-Komorowskiego (Sopicki był w nich ministrem odbudowy administracji publicznej). W jego ocenie powstrzymywanie kraju od akcji zbrojnych i odradzanie tworzenia organizacji konspiracyjnych nie wyczerpywało jednak zagadnienia: „kraj musi czuć - podkreślił Sopicki - że Rząd o nim myśli i stara się wpływać na jego zachowanie się". Apelując o większą aktywność ostrzegał: „,gdyby Rząd milczał, lub gdyby Kraj nic nie wiedział o jego działalności, to różni kierownicy małych grupek konspiracyjnych, działających oczywiście bez związku z Londynem, mogliby uznać się za uprawnionych do organizo-

3 „Diariusz Rady Narodowej Rzeczypospolitej Polskiej” 1949, nr 1, s. 3-4. Zob. też: Inauguracyjne posiedzenie Rady Narodowej, „Orzeł Biały” 1949, nr 24, s. 1-2. Szerzej o stanowisku rządu RP na uchodźstwie wobec sytuacji w Polsce zob. T. Wolsza, Rząd RP na obczyźnie wobec wydarzeń w kraju 1945-1950, Warszawa 1998. W swoich rozważaniach Wolsza nie uwzględnił wystąpień na forum III Rady Narodowej RP.

${ }^{4}$ „Diariusz Rady Narodowej Rzeczypospolitej Polskiej” 1949, nr 1, s. 9. Zob. też: Przemówienie przewodniczacego Rady Narodowej Tytusa Filipowicza, „Orzeł Biały” 1949, nr 25, s. 4.

5 „Diariusz Rady Narodowej Rzeczypospolitej Polskiej” 1949, nr 1, s. 16. Zob. też: Premier Tomaszewski wzywa do jedności, ,Orzeł Biały” 1949, nr 25, s. 5. 


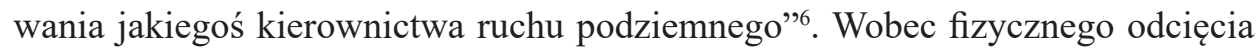
emigracji od kraju, ośmieszania i zohydzania emigrantów przez propagandę komunistyczną trudno było jednak podtrzymywać autorytet władz na uchodźstwie w oczach społeczeństwa w Polsce.

Jerzy Kuncewicz z Klubu Ludowego, wytykając przeciwnikom prezydentury Augusta Zaleskiego na emigracji partyjniactwo i warcholstwo, przypominał: „Zzostaliśmy tutaj [na emigracji], by służyć krajowi. Wszystkie nasze poczynania i nasze zachowane instytucje państwowe oraz nasze organizacje społeczne miały służyć sprawie wyzwolenia”. Polityk SL „Wolność” pytał retorycznie: „czy o tych obowiązkach pamiętamy i czy postępujemy zgodnie z nakazami jakie one nam narzucają?" . Kuncewicz nie wskazywał konkretnie do kogo adresuje swoje krytyczne uwagi, ale wyraźnie odnosiły się one do przeciwników obozu ,zamkowego" na emigracji.

Na trzecim posiedzeniu Rady Narodowej 13 czerwca nadal toczyła się dyskusja nad wystąpieniem premiera. Stanisław Dołęga-Modrzewski (Klub Chrześcijańsko-Społeczny) podkreślił, że komunistyczny aparat represji skutecznie zwalczał jakąkolwiek działalność polityczną w kraju. W obawie przed donosami agentów bezpieki niemożliwe było komunikowanie się ze sobą nie tylko przedstawicieli różnych ugrupowań, ale nawet kilkuosobowe zebrania członków tego samego stronnictwa. W rzeczywistości sytuacja była jeszcze gorsza. Przecież w Polsce w 1949 r. nie istniała już żadna organizacja polityczna, która nie byłaby podporządkowana komunistom. Dołęga-Modrzewski skrytykował też powoływanie się działaczy opozycyjnych partii na emigracji (zwłaszcza Stronnictwa Narodowego) na rzekomą „wolę Kraju”. Emigranci mianowali się reprezentantem zniewolonego kraju, w rzeczywistości sprawa polska stawała się jednak coraz bardziej elementem wewnętrznej rozgrywki między zwolennikami i przeciwnikami prezydentury Zaleskiego na wychodźstwie, choć przecież przyświecał im wspólny cel: Polska wolna, niepodległa i cała.

Na kolejnym posiedzeniu 21 czerwca powołano komisje Rady Narodowej. Jedną z sześciu była Komisja Krajowa w składzie: Stanisław Dołęga-Modrzewski, Jerzy Hryniewski, Jerzy Kuncewicz, Stanisław Sopicki i Karol Ziemski ${ }^{9}$.

Na podstawie dekretu prezydenta Rada Narodowa mogła wydawać własne oświadczenia w sprawach publicznych. Na posiedzeniu 5 lipca jednomyślnie uchwalono odezwę do społeczeństwa polskiego. Zgodnie ze stanowiskiem władz na emigracji Rada Narodowa deklarowała walkę o Polskę w granicach na linii

\footnotetext{
6 „Diariusz Rady Narodowej Rzeczypospolitej Polskiej” 1949, nr 2, s. 22.

7 Ibidem, s. 23.

8 „Diariusz Rady Narodowej Rzeczypospolitej Polskiej” 1949, nr 3, s. 44-45.

9 „Diariusz Rady Narodowej Rzeczypospolitej Polskiej” 1949, nr 4/5, s. 63.
} 
ryskiej ,z ukochanym Wilnem i wiernym Lwowem” oraz na Odrze i Nysie Łużyckiej. Członkowie Rady, „,chyląc czoła przed tymi wszystkimi, którzy w Kraju znoszą mężnie ciężkie doświadczenia przemocy rosyjsko-sowieckiej”, kolejny raz wzywali rodaków do zachowania spokoju, rozwagi i cierpliwości. Zdecydowanie sprzeciwiano się również podejmowaniu walki zbrojnej z rządzącymi w Polsce komunistami: „Wszelkie akty rozpaczy - czytamy w dokumencie - mogłyby w obecnych warunkach ściągnąć na Kraj dalsze nieszczęścia i bezcelowe ofiary" 10 .

\section{PRZECIW SOWIETYZACJI POLSKI}

Na ósmym posiedzeniu Rady Narodowej 20 lipca 1949 r. kierownik Ministerstwa Spraw Wewnętrznych generał Roman Odzierzyński wygłosił przemówienie na temat sytuacji w Polsce. Jednym z głównych problemów, przed którym stało MSW był brak środków finansowych. W rezultacie większość pracowników została zwolniona jeszcze w 1948 r., a kolejni wiosną następnego roku. Latem 1949 r. w MSW pozostało zaledwie czterech urzędników, wykonujących najniezbędniejsze prace. W tych warunkach działania podejmowane przez MSW, podobnie jak przez cały rząd na uchodźstwie, miały bardzo ograniczony charakter. Odzierzyński analizując sytuację w kraju w ostatnich latach podzielił ten okres na dwie fazy. Każda z nich miała inne cechy charakterystyczne i oblicze. Zdaniem szefa MSW na emigracji, pierwsza faza, która rozpoczęła się z chwilą wkroczenia Armii Czerwonej na ziemie polskie i utworzenia tzw. Komitetu Lubelskiego (Polskiego Komitetu Wyzwolenia Narodowego), charakteryzowała się pozornym respektowaniem wolności i swobód demokratycznych, względną wolnością Kościoła i pewną swobodą ekonomiczną. W tym okresie, przypominał Odzierzyński, komuniści kamuflując swoje poglądy w celu zmylenia opinii publicznej chętnie posługiwali się też hasłami patriotycznymi. Jak trafnie podkreślił emigracyjny polityk, przed rządzącym w kraju reżimem stało wówczas wiele zadań i celów (zasiedlenie Ziem Zachodnich, odbudowa kraju ze zniszczeń wojennych), których nie sposób było osiągnąć w otwartej walce z całym narodem. Komuniści nie dysponowali jeszcze rozbudowanym aparatem administracyjnym ani nawet partyjnym. Nie mogli też całkowicie ignorować postawy społeczeństwa. Punktem zwrotnym była połowa 1948 r. Wówczas rozpoczęła się druga faza - forsowna realizacja planów, nakreślonych już od samego początku, które jednak ze względów taktycznych były wcześniej ukrywane. W ocenie Odzierzyńskiego w tym czasie najważniej-

10 „Diariusz Rady Narodowej Rzeczypospolitej Polskiej” 1949, nr 6/7, s. 44-45. Zob. też: Odezwa Rady Narodowej do społeczeństwa polskiego, „Orzeł Biały” 1949, nr 29, s. 2. 
szym wydarzeniem na odcinku politycznym była ostateczna likwidacja Polskiej Partii Socjalistycznej. W roku 1949 kończyła się również, co prawda już tylko formalna, odrębność Polskiego Stronnictwa Ludowego. Polityk emigracyjny przewidywał, że w nieodległej przyszłości dojdzie zapewne do nowego ,zjednoczenia", tym razem Polskiej Zjednoczonej Partii Robotniczej z ruchem ludowym. Podobny los czekać miał Stronnictwo Demokratyczne i Stronnictwo Pracy. Ta polityczna unifikacja prowadzić miała do stworzenia monopartii na wzór sowiecki. Również metody, którymi rządzący posłużyli się do złamania oporu społeczeństwa wzorowane były na metodach sowieckich. Odzierzyński wskazał na rozbudowę aparatu policyjnego, masowe aresztowania, deportacje, mordy polityczne, procesy pokazowe, liczne wyroki śmierci lub długoletniego więzienia czy wymuszanie zeznań torturami. Komuniści rozpoczęli również przebudowę sądownictwa. W rezultacie tych „reform” - stwierdził polityk emigracyjny - „wolność obywatela, jego podstawowe prawo w każdym państwie demokratycznym, znalazła się całkowicie na łasce i niełasce komunistycznego reżymu". Rok 1948 przyniósł ponadto scalenie organizacji młodzieżowych w jeden Związek Młodzieży Polskiej, pozostający całkowicie pod wpływami ideologii komunistycznej. Zmiany nie ominęły także szkolnictwa (nowe programy nauczania i podręczniki). Komuniści przeszli również do ofensywy na odcinku nauki i kultury. Znakiem nowych czasów stała się etatyzacja gospodarki. Propagowany do niedawna trójsektorowy model gospodarczy zastępowany był w coraz większym stopniu przez własność państwową. Na wsi komuniści przystąpili do tworzenia spółdzielni produkcyjnych, wzorowanych na kołchozach. Nieukrywanym celem władz stała się kolektywizacja rolnictwa. Drugą fazę sowietyzacji cechowała także otwarta walka z Kościołem katolickim. Wyrażało się to w skokowym wzroście liczby aresztowanych księży czy szerzonej powszechnie propagandzie bezbożnictwa i nienawiści wobec Kościoła. Rządzący dążąc do ateizacji najmłodszego pokolenia odsuwali Kościół od wpływu na wychowanie dzieci i młodzieży. Wszechobecność PZPR sprawiła, że zacierała się granica między partią komunistyczną a administracją państwową. Mimo ograniczonych możliwości Odzierzyński deklarował, że rząd na uchodźstwie wykorzysta wszelkie okazje, aby przekazywać do kraju wiadomości dotyczące sytuacji politycznej i gospodarczej na świecie. Podobnie jak prezydent czy premier, szef MSW przestrzegał również przed wszczynaniem w kraju walki czynnej ${ }^{11}$.

${ }^{11}$ Po czterech latach rządów agentury moskiewskiej. Przemówienie kierownika Ministerstwa Spraw Wewnętrznych gen. Odzierzyńskiego, „Orzeł Biały” 1949, nr 30, s. 3. Zob. też: „Diariusz Rady Narodowej Rzeczypospolitej Polskiej” 1949, nr 8/9, s. 142-146. 
W dyskusji nad wystąpieniem Odzierzyńskiego, która na forum Rady Narodowej toczyła się 27 lipca i 3 sierpnia, Jan Kazimierski (Klub Ludowy) alarmował o groźbie kolektywizacji rolnictwa. Wskazując na rolę i znaczenie mieszkańców wsi podkreślił: „ludność wiejska winna być w tym okresie specjalnie przestrzegana przed wszelkimi odruchami rozpaczy, a równocześnie informowana o istotnych zamiarach reżimu, gdyż jako ostatnia i podstawowa rezerwa tych wszystkich wartości, które naród polski przez wieki wypracował i przekazał obecnemu pokoleniu jest w kręgu wielkiego nacisku na nią reżimu agentów moskiewskich i powinniśmy dołożyć wszelkich starań, aby była jak najdłużej zachowana w interesie narodu i państwa polskiego"12. Sopicki, zgadzając się generalnie z wystąpieniem Odzierzyńskiego, wytknął mu pominięcie kwestii Kresów (,wschodniej Polski”). Wskazał też na ogromną rolę, jaką w walce z komunizmem w Polsce odgrywa Kościół poprzez działalność wychowawczą ${ }^{13}$.

Michał Grażyński (Klub Ligi Niepodległości), przemawiając w drugiej części dyskusji, skoncentrował się na odcinku młodzieżowym oraz znaczeniu polityki informacyjnej emigracyjnych władz. Podkreślił, że rząd RP musi znaleźć sposób na docieranie do rodaków w kraju z własną informacją. Jak zaznaczył: ,żadne "voice " nie może jej zastąpić”. Mając świadomość związanych z tym problemów dodał: „trudności nie uzasadniają nigdy jednak bezczynności, a przeciwnie, winy stać się podnietą do poszukiwania rozwiązań”"14. W ocenie Stanisława Jóźwiaka (Klub Chrześcijańsko-Społeczny) najważniejszym zagadnieniem była obrona społeczeństwa polskiego przed wyniszczeniem biologicznym. W związku z tym obowiązkiem rządu RP było wydawać właściwe dyrektywy i przekazywać je do kraju, tak, aby dotarły do zainteresowanych ${ }^{15}$. Przy okazji dyskusji nad exposé szefa MSW, arcybiskup Sawa (Jerzy Sowietow) jako zwierzchnik Kościoła prawosławnego na uchodźstwie przedstawił sytuację wyznawców prawosławia w Polsce. Po usunięciu ze stanowiska metropolity Dionizego i uniemożliwieniu mu przez komunistów sprawowania jakiejkolwiek funkcji, jego miejsce zajął biskup Tymoteusz. Podporządkował on cerkiew w kraju patriarchatowi moskiewskiemu $^{16}$. Generał Marian Januszajtis zarzucił ministrowi Odzierzyńskiemu, że przedstawiając sytuację w kraju nie wspomniał w ogóle o ruchu narodowym, który - w jego ocenie - miał dominujący wpływ na kształtowanie się myśli politycznej i duchowej kraju. Januszajtis dodał, że zarówno robotnik, jak i chłop polski sprzeciwiali się marksistowskiej teorii walki klas ${ }^{17}$.

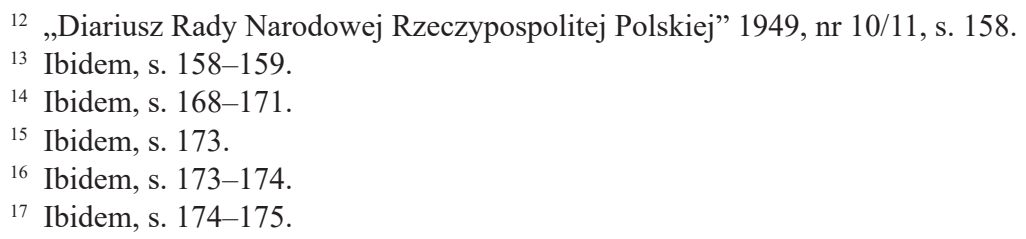

15 Ibidem, s. 173.

${ }^{16}$ Ibidem, s. 173-174.

${ }^{17}$ Ibidem, s. 174-175. 
Kilka miesięcy później, 14 listopada, premier Tomaszewski mówił w Radzie Narodowej o dalszym zaostrzeniu sowietyzacji i rusyfikacji w kraju. Świadectwem tego były „czystki” w aparacie partii komunistycznej, uczynienie Konstantego Rokossowskiego „faktycznym wielkorządcą Polski” czy nowe prześladowania religii i Kościoła katolickiego ${ }^{18}$.

\section{PRZECIW PROWOKACJOM I WALCE ZBROJNEJ W POLSCE}

Po II wojnie światowej władze RP na uchodźstwie kilkakrotnie przestrzegały rodaków w kraju przed uleganiem nastrojom powstańczym. Wobec ponownego zaostrzenia w stosunkach międzynarodowych na tle konfliktu w Korei, generał Odzierzyński jako minister obrony narodowej i kierownik MSW, w oświadczeniu wygłoszonym na posiedzeniu Rady Narodowej 6 lipca 1950 r. ponownie ostrzegał kraj przed „wszelkiego rodzaju prowokacjami”. Polityk emigracyjny obawiał się, że mogą one być podsycane za pomocą ulotek, radia bądź ustnego podburzania przez ,agentów obcych oraz różne nieodpowiedzialne czynniki”, w celu wywołania w Polsce działań, „mogących w obecnym stanie pociągnąć za sobą jedynie represje i bezowocne ofiary, których i tak Naród nasz poniósł niewspółmiernie dużo w porównaniu z innymi”. W przekonaniu emigrantów jedynie władze na uchodźstwie mogły wezwać rodaków w kraju do „nowych wysiłków i ofiar”, ale dopiero wówczas, gdy „nabiorą pewności, że wysiłki te nie pójdą na marne, a istotnie służyć będą przywróceniu Ojczyźnie niepodległości, wolności i całości”'19. Oszczędzanie sił biologicznych narodu, wyniszczonych podczas niedawno zakończonej wojny, uważano w „polskim” Londynie za wartość nadrzędną. Równie istotna była racja stanu Polski. Władze na uchodźstwie uważały się za jej jedynego i pełnoprawnego depozytariusza.

Trzy miesiące później Odzierzyński, już jako nowy premier, przedstawił na posiedzeniu Rady Narodowej program swojego gabinetu. Szef rządu podkreślił, że im bardziej zaostrza się sytuacja polityczna w świecie, tym ostrożniej władze na emigracji będą się wypowiadać na temat kraju. Premier deklarował, że rząd na uchodźstwie nie ustanie jednak w demaskowaniu komunistycznych władz w Polsce czyli - jak określił - „agentury narzuconej narodowi polskiemu i sprawującej nad nim rządy terroru i bezprawia". Za jedną z najważniejszych kwestii dotyczącą spraw krajowych uważał nasilenie akcji informacyjnej za pomocą audycji radiowych $^{20}$.

\footnotetext{
18 „Diariusz Rady Narodowej Rzeczypospolitej Polskiej” 1949, nr 15, s. 234.

19 Rzad RP ostrzega Kraj i emigracje, „Orzeł Biały” 1950, nr 28, s. 1.

${ }^{20}$ Program nowego rzadu RP, „Orzeł Biały” 1950, nr 41, s. 8.
} 
Rząd RP na uchodźstwie nie mając środków ani możliwości zorganizowania własnej łączności radiowej z krajem korzystał z pośrednictwa Radia Madryt. Była to wówczas jedyna dostępna forma łączności z krajem. Na początku 1949 r. przy Radio Nacional de España powstała sekcja polska, dysponująca znaczną autonomią programową. Radio Madryt nadawało codziennie półgodzinną audycję w języku polskim (biuletyn informacyjny, komentarz prasowy, pogadanki o ogólniejszym charakterze). Audycje docierały do Polski, gdzie na początku lat pięćdziesiątych cieszyły się pewną popularnością (zwłaszcza zanim z Monachium zaczęła nadawać Rozgłośnia Polska Radia Wolna Europa) ${ }^{21}$.

Za pośrednictwem Radia Madryt Odzierzyński planował przekazywać Polakom w kraju informacje o sytuacji w świecie oraz o działalności rządu RP na uchodźstwie. Obok akcji informacyjnej premier kładł nacisk na systematyczne monitorowanie sytuacji w Polsce: „Przemiany, zachodzące w Kraju - mówił Odzierzyński - winny być pilnie obserwowane. Musimy dokładnie zdawać sobie sprawę z nasilenia sowietyzacji Polski i wciągania jej bez reszty w układ komunistycznego systemu". Kluczowe znaczenie miało również utrzymywanie choćby pośredniej łączności z krajem: „nie możemy dopuścić - podkreślił emigracyjny premier - abyśmy się stali obcymi w rzeczywistości polskiej"22.

27 października 1950 r. prezydent Zaleski zamknął pierwszą sesję III Rady Narodowej RP. W wygłoszonym z tej okazji przemówieniu odniósł się również do sytuacji w Polsce. Jak przypuszczał, kraj „będzie musiał jeszcze wytrzymać wiele ciężkich chwil”. Stale pogarszające się warunki bytu, wzmagająca się akcja skomunizowania i rusyfikacji Polski nie dawały nadziei na szybką poprawę sytuacji. Polacy w kraju musieli w coraz większym stopniu dostosowywać się do otaczającej ich ponurej rzeczywistości. Alternatywą była otwarta wojna domowa, która doprowadziłaby ,jedynie do nieszczęść i do dalszych niepotrzebnych ofiar”23.

${ }^{21}$ Sekcją polską Radia Madryt kierował Karol Wagner (prawdziwe nazwisko Pieńkowski), a jej długoletnim współpracownikiem był znany publicysta i poeta Józef Łobodowski, mieszkający w Hiszpanii. Szerzej zob. M. Bogdan, Radio Madryt 1949-1955. Powstanie, organizacja oraz funkcjonowanie polskiej sekcji Radio Nacional de España w pierwszym okresie działalności, Warszawa 2011; P. Libera, Józef Łobodowski i polska audycja Radia Madryt (1949-1975), [w:] Polska a Hiszpania. $Z$ dziejów koegzystencji dwóch narodów w XX wieku, red. M. Białokur i P. Jakóbczyk-Adamczyk, Torun-Opole-Piotrków Trybunalski 2012, s. 156-187; J. Łobodowski, ,, Tu mówi Madryt”, „Zeszyty Historyczne” 1980, z. 54, s. 113-128; P. Machcewicz, Emigracja w polityce międzynarodowej, Warszawa 1999, s. 218-220; K. Tarka, Wspólnota losu. Rząd RP na uchodźstwie a Hiszpania po II wojnie światowej [w:] Polska a Hiszpania ..., s. 142-143. Na łamach „Kultury” paryskiej sytuację w Polsce na podstawie korespondencji napływającej z kraju do Radia Madryt omówił J. Łobodowski, Sytuacja w kraju poprzez korespondencję, „Kultura” 1950, nr 11, s. 71-81 oraz Wotania o ratunek, „Kultura” 1951, nr 5, s. 108-110.

${ }^{22}$ Program nowego rządu RP, „Orzeł Biały” 1950, nr 41, s. 8.

${ }^{23}$ Prezydent RP zamknąt sesję Rady Narodowej, „Orzeł Biały” 1950, nr 44, s. 1. 


\section{O POLSKĄ RACJĘ STANU}

Przemówienie na otwarcie drugiej sesji Rady Narodowej 3 lutego 1951 r. prezydent poświęcił ocenie sytuacji międzynarodowej. Choć wojna w Korei toczyła się daleko od granic Polski, to Zaleski obawiał się, że kraj może zostać wciągnięty w wir wydarzeń: „Pożar wybuchł daleko od nas - stwierdził obrazowo - lecz wiatr od wschodu może przenieść go w nasze strony”. Prezydent nie miał wątpliwości, że miejsce Polski jest po stronie Zachodu. Ostrzegał jednak: „być może, w miarę kruszenia się budowy jałtańskiej, pojawią się próby wyzyskania polskich uczuć i gotowości do walki z najeźdźcą - w czasie i okolicznościach niezgodnych z polskim interesem politycznym. Trzeba odróżnić te pokusy - apelował Zaleski od prawdziwej polskiej racji stanu" ${ }^{24}$. Na straży tego interesu stać miały władze RP na uchodźstwie. Mimo prozachodniej opcji, wśród „,zamkowych” polityków widoczna była nieufność wobec Waszyngtonu czy Londynu. Prezydent, podobnie jak inni działacze z jego otoczenia, konsekwentnie przestrzegając rodaków w kraju przed prowokacjami, obawiał się, że zapał Polaków mógłby być kolejny raz wykorzystany do nie polskich interesów. Zaleski nie uważał za celowe automatyczne akceptowanie przez władze RP na uchodźstwie każdych poczynań Zachodu w sprawie polskiej. Niestety, „zamkowi” politycy, wytykając Amerykanom czy Brytyjczykom instrumentalne traktowanie sprawy polskiej, domagając się podmiotowego traktowania Polski i rządu RP na uchodźstwie, w rezultacie pogłębiali swoją izolację na arenie międzynarodowej, a tym samym jeszcze bardziej ograniczali i tak niewielkie możliwości działania ${ }^{25}$.

Jak wynika z projektu budżetu przedłożonego na tym samym posiedzeniu Rady przez nowego ministra skarbu Stanisława Sopickiego, wydatki Ministerstwa Spraw Wewnętrznych ustępowały jedynie funduszom Ministerstwa Spraw Zagranicznych oraz Ministerstwa dla Spraw Obywateli Polskich na Obczyźnie. Proponowane w budżecie kwoty odzwierciedlały hierarchię spraw w działaniach rządu. W budżecie MSW priorytetowe były trzy zagadnienia: informowanie świata o sowietyzacji Polski, informowanie kraju o sytuacji międzynarodowej za pośrednictwem Radia Madryt oraz studia nad zmianami gospodarczymi i socjalnymi w Polsce ${ }^{26}$.

Podczas dyskusji w Radzie Narodowej 9 lutego nad wystąpieniem ministra Sopickiego, Stanisław Ścigalski zwrócił uwagę na potrzebę należytego informowania zagranicy i kraju. W imieniu Klubu Ludowego postawił wniosek o uruchomienie przez rząd własnej stacji radiowej oraz wydawanie pisma w języku angiel-

\footnotetext{
${ }^{24}$ Mowa Prezydenta RP na otwarcie sesji Rady Narodowej, „Orzeł Biały” 1951, nr 6, s. 1.

${ }^{25}$ Szerzej zob. K. Tarka, Emigracyjna dyplomacja. Polityka zagraniczna rzadu RP na uchodźstwie 1945-1990, Warszawa 2003.

${ }^{26}$ Budzet rządu RP na rok 1951-2, „Orzeł Biały” 1950, nr 7, s. 8.
} 
skim. Michał Grażyński (Klub Ligii Niepodległości) domagał się uruchomienia Komitetu oraz Instytutu dla Badania Spraw Krajowych ${ }^{27}$. Na jednym z kolejnych posiedzeń Rady Narodowej również Dołęga-Modrzewski podkreślił znaczenie akcji radiowo-informacyjnej dla kraju ${ }^{28}$.

Gdy 18 maja 1951 r. Rada Narodowa debatowała nad sytuacją Autokefalicznego Kościoła Prawosławnego w Polsce, członek Rady, prawosławny arcybiskup Sawa, zasłabł podczas posiedzenia i zmarł trzy dni później. Na kolejnym posiedzeniu 25 maja Rada potępiła „bezprawne poczynania” władz warszawskich i patriarchatu moskiewskiego dotyczące organizacji cerkwi prawosławnej w Polsce. W obszernym sprawozdaniu Komisji Kultury i Oświaty przypomniano, że już w 1948 r. metropolita warszawski Dionizy pod naciskiem władz komunistycznych został usunięty ze stanowiska. Jego następca arcybiskup Tymoteusz „wyrzekł się" autokefalii otrzymanej w 1924 r. od patriarchatu konstantynopolitańskiego i opowiedział się za wznowieniem „wspólnoty modlitewnej” z patriarchatem moskiewskim ${ }^{29}$.

\section{OSTATNIE POSIEDZENIE}

Ostatnie posiedzenie III Rady Narodowej 5 czerwca 1951 r. w całości poświęcone było sprawom krajowym. Obszerne przemówienie o sytuacji w Polsce wygłosił minister spraw wewnętrznych Jerzy Hryniewski. Szef MSW nie miał wątpliwości, że komuniści wzorując się na doświadczeniach i wskazówkach płynących z Kremla zmierzali do budowy Polski sowieckiej. Jak podkreślił, w połowie 1948 r. sowietyzacja Polski nabrała przyspieszenia. W rezultacie na początku 1951 r. niemal cały przemysł w Polsce był już upaństwowiony. Na wsi rozpędu nabierała kolektywizacja rolnictwa. Jeśli na początku 1950 r. były „tylko” 243 spółdzielnie produkcyjne, to rok później ich liczba przekroczyła dwa tysiące. Tylko w pierwszym kwartale 1951 r. przybyło kolejne 700 spółdzielni. W końcu roku w całej Polsce miało już być pięć tysięcy spółdzielni produkcyjnych. Postępy czyniła również bolszewizacja oraz barbaryzacja nauki i kultury w kraju. Jej symbolem była postanowiona już likwidacja Polskiej Akademii Umiejętności, którą zastąpić miała oparta na wzorach sowieckich Polska Akademia Nauk. Nasiliła się również walka z Kościołem katolickim, który pozostał jedyną organizacją

${ }^{27}$ Archiwum Instytutu Polskiego i Muzeum im. gen. W. Sikorskiego [dalej: AIPMS], Rada Narodowa, A.5/113, Posiedzenie Rady Narodowej RP 03.02.1951 r.

${ }^{28}$ Ibidem, Posiedzenie Rady Narodowej RP 06.04.1951 r.

${ }_{29}^{2}$ Zgon arcybiskupa Sawy, „Orzeł Biały” 1951, nr 21, s. 8; Uczczenie pamięci arcybiskupa Sawy, „Orzeł Biały” 1951, nr 22, s. 4-5; Położenie Autokefalicznego Kościoła Prawosławnego w Polsce, „Orzeł Biały” 1951, nr 24, s. 5. 
„polską” (niepodporządkowaną komunistom) w kraju. Znaczne zmiany zaszły w ustroju administracyjnym państwa. W miejsce zlikwidowanych urzędów wojewodów, starostów, prezydentów miast, burmistrzów i wójtów utworzono rady narodowe i ich prezydia. W końcu 1950 r. „zreformowano” również sądownictwo uchwalając nowy kodeks postępowania karnego ${ }^{30}$.

Według Hryniewskiego, choć Stronnictwo Ludowe (faktycznie Zjednoczone Stronnictwo Ludowe) czy Stronnictwo Demokratyczne „zachowały jeszcze swoje szyldy", to w rzeczywistości partia komunistyczna miała monopolistyczny charakter. Kraj zalewała literatura komunistyczna o propagandowym charakterze. Szef MSW nie miał wątpliwości, że rządząca Polską mniejszość narzuciła swoją wolę większości społeczeństwa. Jak stwierdził: „200 000 aktywu partyjnego w oparciu o UB i armię Rokossowskiego narzuca swą wolę 25 milionom Polaków!” Hryniewski dodał: „wobec postawy społeczeństwa nie byłaby to jeszcze walka nierówna, gdyby za Kompartią, UB i Rokossowskim nie stała Rosja Sowiecka”. W ocenie polityka emigracyjnego postawa rodaków w kraju, opuszczonych przez Zachód, była „godna najwyższego uznania i szacunku". W ogniu wojny i dwóch okupacji kraj dojrzał, zmężniał i zahartował się - podkreślał z uznaniem Hryniewski. Z perspektywy „polskiego” Londynu ogół społeczeństwa trwał w biernym oporze. Kraj, mówił z emfazą szef MSW, „zaciął się i walczy w milczeniu, broniąc nieustępliwie na każdym dosłownie odcinku życia i progu swego ogniska domowego, naszej odrębności narodowej i naszego stylu życia". Według niego kraj oczekiwał wyzwolenia, ale równocześnie zdawał sobie sprawę z jego „kosztów i niebezpieczeństw”. Hryniewski był przekonany, że wielu Polaków w kraju wiedziało o działalności władz na uchodźstwie i miało do nich zaufanie. Przyznał, że ich głównym źródłem informacji były audycje Radia Madryt. Na podstawie głosów docierających z Polski twierdził, że rodacy w kraju oczekują od emigracji „oględności, rozwagi i niepopełniania błędów, podobnych do tych z czasu wojny”. Kraj miał się zdecydowanie sprzeciwiać „,polityce awantur i nieprzemyślanych odruchów”. Do emigrantów docierały tylko szczątkowe wiadomości o sytuacji na Kresach (,we wschodniej Polsce"). Jeśli na obszarze podległym władzy Bieruta sowietyzacja miała charakter „bardziej ewolucyjny i ze względu na opinię świata zachowywała pozory demokratyzmu”, to na terenach „za linią Mołotow-Ribbentrop” przebiegała gwałtownie, w sposób rewolucyjny. W imieniu rządu RP i całego wychodźstwa szef MSW deklarował: „nasz stosunek do tych ziem i ich ludności się nie zmienił". Zapowiadał, że rząd na uchodźstwie będzie podejmował wobec ziem wschodnich podobne działania, jak wobec pozostałych części Polski,

\footnotetext{
${ }^{30}$ [J. Hryniewski], Budowa Polski sowieckiej, „Orzeł Biały” 1951, nr 25, s. 4.
} 
aby doprowadzić do ich uwolnienia ${ }^{31}$. Rząd RP stał niezmiennie na stanowisku obrony granicy ryskiej na wschodzie.

Minister przedstawił też plan pracy MSW na najbliższą przyszłość. Jak zaznaczył, ze względu na ograniczone środki finansowe program ten musiał być dostosowany do możliwości władz na emigracji. Hryniewski zapowiedział uruchomienie Studium Zagadnień Krajowych. Współpracujący z tą instytucją eksperci emigracyjni mieli w sposób „systematyczny i programowy” analizować wydarzenia w Polsce. Pierwsze zebranie Studium już się nawet odbyło, nadal trwały jednak prace statutowo-organizacyjne. Miało się ono składać z czterech sekcji (prawnej, ekonomiczno-gospodarczej, technicznej i oświatowej) oraz dostarczać emigrantom wiedzę o „prawdziwej sytuacji” w kraju. Minister zobowiązał się, że Studium otrzyma wszystkie dostępne na emigracji wydawnictwa krajowe, zwłaszcza prasę codzienną. Kontynuowana miała być również współpraca z Radiem Madryt i innymi rozgłośniami radiowymi, które przekazywałyby do kraju informacje o działalności emigracji politycznej i pracach rządu RP. W ocenie Hryniewskiego rozgłośnia madrycka była z uwagą słuchana w Polsce. Na zakończenie wystąpienia szef MSW zapewniał, że rząd na uchodźstwie solidaryzuje się z postawą rodaków w kraju, docenia ich opór, ale także rozwagę i determinację oraz rozumie ich tragiczną sytuację ${ }^{32}$.

Po przemówieniu ministra Hryniewskiego, wiceprzewodniczący III Rady Narodowej Dołęga-Modrzewski zgłosił projekty dwóch odezw: do kraju oraz do parlamentów świata i Organizacji Narodów Zjednoczonych. Oba dokumenty zostały uchwalone bez sprzeciwu. W pierwszym z nich emigranci zapewniali o swojej łączności z „cierpiącym i walczącym” krajem. Nie mieli wątpliwości, że Polska znajdowała się pod nową i ciężką okupacją. Charakteryzował ją brak wszelkich wolności, deptanie honoru i godności narodowej, system terroru, ekonomiczny wyzysk robotników, praca ponad siły, polityczna indoktrynacja, walka z religią oraz z tysiącletnią kulturą i tradycją polską. Idealizując postawę rodaków w kraju, Rada Narodowa wyrażała uznanie dla ich niezłomnego i pełnego wierności dla ideałów zachowania. W odezwie podkreślono, że „w Kraju, tak jak w obozie koncentracyjnym, każdy akt oporu spotka się z miażdżącą reakcją siepaczy reżymu, zdecydowanych na przelanie krwi w obronie czerwonego caratu". W tej sytuacji obowiązek prowadzenia niezależnej polityki polskiej oraz walki o niepodległość Polski spadał na emigrację. Po raz kolejny apelowano do rodaków w kraju, aby powstrzymali się „od wszelkich poczynań, które, nie przyczyniając się bezpośrednio do poprawy położenia Narodu, mogą ściągnąc nań wyniszczające represje. Kraj - podkreślono - musi wystrzegać się wszelkich prowokacji, skądkolwiek by

\footnotetext{
${ }^{31}$ [J. Hryniewski], Budowa Polski sowieckiej, „Orzeł Biały” 1951, nr 26, s. 2.

32 Ibidem.
} 
one szły i nie dać się ponieść nieobliczalnym odruchom". W przyjętym równocześnie apelu do parlamentów świata i ONZ przestrzegano przed traktowaniem wypowiedzi przedstawicieli reżymu komunistycznego w Polsce jako głosu narodu polskiego. Ostrzegano też ,przed złudzeniami budowania pokoju świata za cenę oddania Sowietom w jarzmo i na zniszczenie narodów Europy Środkowej”33. W ocenie członków Rady Narodowej Polska rządzona przez komunistów znajdowała się w rzeczywistości pod okupacją, przypominała wręcz wielki obóz koncentracyjny.

W dyskusji nad przemówieniem ministra Hryniewskiego głos zabrali przedstawiciele wszystkich klubów w Radzie Narodowej. Jako pierwszy wystąpił Stefan Mękarski (Klub Ligii Niepodległości). Mówca, znany publicysta, specjalizujący się $\mathrm{w}$ analizach sytuacji w kraju, położył główny nacisk na zagadnienie „przewrotu kulturalnego” w Polsce. Mękarski obawiał się, że jeśli sytuacja w kraju w dłuższym okresie czasu nie ulegnie zmianie, to w przyszłości (nie precyzował jednak kiedy) w Polsce może się wykształcić „typ kulturalny człowieka, z którym porozumienie Polaka wolnego stawać się będzie coraz trudniejsze". Pozytywnie oceniał natomiast zachodzący w kraju po II wojnie światowej proces unarodowienia całej ludności. Mękarski uważał, że był to proces o rodzimym charakterze, choć został on przez terror i okupację przyspieszony. Z uznaniem powitał też zapowiedź utworzenia Studium Badania Spraw Krajowych. Dla Jadwigi Dobruckiej (Klub Ludowy) najważniejszą kwestią było przekazywanie do kraju rzetelnych informacji za pośrednictwem radia: „Kraj - mówiła - żądny jest wiadomości z zagranicy. Ciekawość i głód prawdy rosną w miarę tego, jak zwiększa się pod okupacją ucisk kłamstwa. Toteż mimo utrudnień technicznych głos wolny i niezależny, dochodzący na falach eteru, ma echo niezmiernie żywe w Kraju”. „Szczególnie pilnie” miały być słuchane audycje Radia Madryt. Alfred Marski (Klub Chrześcijańsko-Demokratyczny), apelując do emigrantów o skupienie się wokół głowy państwa i rządu RP, oświadczył: „pozostaliśmy za granicą na dobrowolnym wygnaniu jedynie dla służby Krajowi, którego haniebne traktaty jałtańskie i teherańskie oddały w obcą niewolę. Wszystkie nasze prace i myśli dążą jedynie do wywalczenia wolności naszej uciemiężonej Ojczyźnie”. Zygmunt Szadkowski (Niezależna Grupa Społeczna) skoncentrował się na zagadnieniu młodzieży w Polsce. Podkreślił, że w kraju jako wzór do naśladowania wskazuje się młodzieży „ludzi sowieckich”. Jednocześnie komuniści zohydzają dzieje Polski oraz dążą do zerwania więzów rodzinnych i religijnych. Propagowany przez komunistów kult pracy i maszyny przy równoczesnym wyeliminowaniu Boga z przestrzeni publicznej przygotowywał według niego grunt dla niewolnictwa i pochodu barbarzyństwa. Stefan Tyszkiewicz (Klub Ziem Wschodnich)

\footnotetext{
${ }^{33}$ AIPMS, Rada Narodowa, A.5/113, Posiedzenie Rady Narodowej RP 05.06.1951 r.
} 
wyraził zadowolenie z obecności w pracach Rady Narodowej tematyki kresowej. Adam Pragier (Klub Związku Socjalistów Polskich) podkreślił, że „nad wszystkim, co się w Polsce dziś dzieje, panuje potworna, niebywałego rozmiaru maskarada. Moskwa - dowodził Pragier - nakazała swojemu agentowi, by nazwał się prezydentem Rzeczypospolitej, on tego rozkazu słucha. Innej grupie agentów nakazała Moskwa udawać rząd polski i oni tego rozkazu słuchają. Podbity kraj, którego połowę oddarto, nazywa się krajem niepodległym. Mongolski system totalitarny maskuje się jako rewolucja socjalna”. Znany publicysta i polityk emigracyjny miał jednak nadzieję, że bieg dziejów niebawem przerwie tę maskaradę ${ }^{34}$.

$\mathrm{Na}$ zakończenie głos zabrał prezydent Zaleski, który zamknął dwuletnią kadencję III Rady Narodowej. Za jedno z najważniejszych zadań emigracji prezydent uważał informowanie kraju o działalności rządu na uchodźstwie. Kolejny raz ostrzegał też rodaków w kraju przed obcymi prowokatorami i podejmowaniem działań, które mogłyby narazić kraj na „nowe niepotrzebne ofiary”35.

\section{ZAKOŃCZENIE}

W czerwcu 1949 r., ponad cztery lata od rozwiązania II Rady Narodowej, prezydent Zaleski powołał III Radę Narodową. Przyczyniło się to do konsolidacji ugrupowań tworzących obóz prezydencki (,zamek”), jednak największe partie polityczne na emigracji (PPS, SN i PSL) kontestowały prezydenturę Zaleskiego. W następnych latach, mimo prób pojednania, spór jeszcze się pogłębił. Sytuacja w Polsce, obok problemów wewnątrzemigracyjnych oraz emigracyjnej dyplomacji, była jednym z trzech głównych zagadnień dyskutowanych na posiedzeniach Rady Narodowej. Emigracyjni politycy odrzucali powojenną rzeczywistość w kraju. Uważali, że Polska znajduje się pod okupacją, a w kraju władzę sprawuje narzucona agentura. Polskę rządzoną przez komunistów przyrównywano do obozu koncentracyjnego. Ponieważ kraj nie mógł wypowiadać swobodnie swojej woli, to na emigracji ciążył obowiązek prowadzenia akcji politycznej w jego obronie. Celem była Polska wolna, niepodległa i cała.

Wiadomości napływające z kraju wskazywały, że rządzący nad Wisłą komuniści zmierzali do całkowitej sowietyzacji, czyli upodobnienia Polski do sowieckiego wzoru. Emigracyjni politycy wielokrotnie apelowali (także na forum Rady Narodowej) do rodaków w kraju o zachowanie spokoju, oszczędzanie sił, nieuleganie prowokacjom i niepodejmowanie walki zbrojnej. Obawiali się, że antykomunistyczne powstanie zakończyłoby się klęską i przyniosło tylko kolejne bezcelowe ofiary.

${ }^{34}$ Ibidem.

35 Zamknięcie III Rady Narodowej RP. Mowa Prezydenta Rzeczypospolitej Augusta Zaleskiego, „Orzeł Biały” 1951, nr 23, s. 1. 
Oszczędzanie sił biologicznych narodu, wyniszczonych podczas niedawno zakończonej wojny w ,polskim” Londynie uważano za wartość nadrzędną.

Politycy obozu „zamkowego" nie mając bezpośredniej łączności z krajem wykorzystywali Radio Madryt do przekazywania informacji o działalności władz RP na uchodźstwie. Jeśli rząd RP miał być głosem zniewolonego kraju, miał reprezentować polskie interesy i sprawę polską na arenie międzynarodowej, to kluczowym zadaniem wychodźstwa było utrzymanie autorytetu tegoż rządu w oczach rodaków w Polsce. Emigranci starali się również obserwować i analizować krajową rzeczywistość. Ograniczone możliwości finansowe i kadrowe oraz brak łączności z krajem utrudniały tego typu działania. Wychodźstwo, coraz bardziej pogrążone $\mathrm{w}$ wewnętrznych sporach, nie stworzyło programu politycznego prowadzącego do odzyskania niepodległości przez Polskę. Polityczna izolacja rządu RP na arenie międzynarodowej sprawiła, że emigranci mogli tylko trwać na posterunku i czekać na zmianę koniunktury międzynarodowej.

"WE ARE HERE FOR POLAND”. THE THIRD NATIONAL COUNCIL
OF POLAND IN THE LIGHT OF THE EVENTS IN THE COUNTRY (1949-1951)

Abstract

The article presents discussions on the situation in Poland which took place at the forum of the Third National Council. The Council was appointed by the president of Poland in Exile August Zaleski in 1949. It was vicariously performing some of the functions of the Parliament and as such it was an advisory body to the president and to the government. Its term of office lasted for two years (between 1949 and 1951). Polish authorities in exile regarded Poland as an occupied country and that it was ruled by imposed agents. News coming from the country indicated that the communists ruling in Poland were steering it toward its total sovietisation. Politicians in emigration appealed numerous times to their fellow countrymen in the homeland not to undertake armed combat. They feared that an anti-communist uprising would end in disaster. Their goal was free Poland, independent and whole. However, they could not create a programme which would enable achieving this goal.

«NOUS SOMMES ICI POUR LA POLOGNE». LE IIIÈME CONSEIL NATIONAL

DE LA RÉPUBLIQUE DE POLOGNE ENVERS LES ÉVÉNEMENTS DANS

LE PAYS (1949-1951)

Résumé

L'article présente les discussions au sujet de la situation en Pologne menées lors du forum du IIIème Conseil National. Le Conseil a été établi par le président de la République de Pologne en exil August Zaleski en 1949. Remplaçant certaines fonctions du parlement, 
le Conseil était un organe consultatif du président et du gouvernement. Le mandat du IIIème Conseil National a duré deux ans (1949-1951). Les autorités de la République de Pologne en exil croyaient que la Pologne se trouvait sous occupation, et le pays était gouverné par une autorité imposée. Les messages venant du pays indiquaient que les communistes gouvernant en Pologne visaient à sa soviétisation totale. Les politiciens restant en exil ont lancé plusieurs appels aux compatriotes dans le pays pour qu'ils n'entament pas la lutte armée. Ils craignaient que le soulèvement anti-communiste se termine par une défaite. Leur objectif était la Pologne libre, indépendante et entière. Cependant, ils ne savaient pas créer un programme pour atteindre le but. 